\title{
Diagnostic of customer-centeredness of university organizational culture
}

\author{
I. V. Shavyrina \\ Department of Sociology and Management \\ Belgorod State Technological University \\ named after V. G. Shukhov \\ BSTU named after V.G. Shoukhov \\ Belgorod, Russia \\ shavyrina_77@mail.ru
}

\author{
I. A. Demenenko \\ Department of Sociology and Management \\ Belgorod State Technological University \\ named after V. G. Shukhov \\ BSTU named after V.G. Shoukhov \\ Belgorod, Russia \\ inna12manager@gmail.com
}

\author{
M. N. Reutova \\ Department of Social Technologies \\ Belgorod National Research University \\ BelSU \\ Belgorod, Russia \\ reutova@bsu.edu.ru
}

\begin{abstract}
The article examines customer-centeredness development of organizational culture of higher education institutions and the extent at the regional level. The study was conducted based on the diagnostic model of university customercentered organizational culture developed by the authors. The model included such parameters as the extent of university organizational customer-centered culture at various levels (general ideological, regulatory, front-office), the degree of satisfying the requirements of students for the university environment, as well as the degree of students' involvement in the organizational culture of a university and the effectiveness of university organizational cultural impact on them. The study led to the conclusion that the strategy for modern university development, on the one hand, is aimed at meeting the needs of students, and, on the other hand, the student is not a main motivator of university development. Customer-centered organizational culture is rather external and demonstrative, rather than domestic, and the university environment is not likely to ensure the commitment of internal and external customers.
\end{abstract}

Keywords- customer-centeredness, university, organizational culture and higher education.

\section{INTRODUCTION}

The term "customer-centeredness", which emerged in the science of management, was formulated and implemented in the field of business, where it was understood as a special strategic approach to the development of the organization, ensuring its competitiveness and increasing profitability and implying the mobilization of all its resources to identify, involve and attract new customers and retain the most profitable ones by means of customer service quality increase and customers' needs satisfaction [1]. It should be noted that there is no common understanding of "customer-centeredness" as a control phenomenon. The difference between the approaches is due to the reflection of a specific aspect of customer focus. Accordingly, there are strategic, value-based, behavioral and process approaches to defining the essence of the "customer-centeredness" concept. Despite the obvious differences caused by different approaches to consideration of customer-centeredness, it should be noted that the creation of added value can be regarded as the desired result of a customer focus. Thus, a wide range of institutional arrangements and processes can be allocated. They make up the final customer focus: value provisions ensuring the more attentive attitude of staff towards customers' needs; higher priority of customers' interests compared with other stakeholders' groups; and a clear understanding of the goals and strategy of a company. Thus, customer-centeredness is a cross-functional process, covering all organizational levels.

This paper regards custom-centered university organizational culture as a system of values, behavioral norms, traditions, rituals, and symbols oriented at the student personality in order to achieve maximum efficiency from the educational process [2]. In the authors' view, university customer-centered organizational culture by no means diminishes the primary role of the university as a social institution for the production of culture, intellectual potential, civic consciousness and spirituality, but rather complements it. Education quality, teaching staff professionalism and innovation, as well as other criteria, have always been and will be the criteria by which a university is assessed. But, nevertheless, the emergence and development of an education market and effective education system formation have posed a number of strategic challenges for educational institutions, and, in particular, for higher education institutions. The challenges are because universities need to adapt to the specific market conditions that determines the change in universities' development focus. 


\section{LITERATURE REVIEW}

The ambiguity of the organizational culture phenomenon predetermined the existence of multiple approaches to the understanding of this phenomenon in research practice. Jesper $\mathrm{K}$. was among the first foreign researchers to carry out the first attempt at understanding the methodological bases of the organizational culture phenomenon [3]. He considered organizational culture as "corporate religion", including the confidence of an organization in itself and in its dreams. K. Cameron and Robert Quinn proposed a comprehensive typology of organizational culture, including two groups of criteria: the main indicators of a company's effectiveness and activities focus [4]. According to the theory of F. Harris and R. Moran the contents of organizational culture are not defined not by the aggregate of mere expectations and real state of each characteristic, but by their interrelation and their capability to form the profiles of certain cultures [5]. S. P. Robbins defines organizational culture from the perspective of such characteristics as personal initiative, risk, actions, coherence and direction, management support, monitoring, identity, reward system, proneness to conflict and interaction models [6]. From the position of E. H. Schein, organization culture is a pattern (i.e. scheme or model) of collective basic conceptions gained by a group when resolving the problems of adaptation to changes in the external environment and internal integration [7]. According to G. Hofstede, organizational culture is determined, above all, by the values which are common to most employees [8].

At the present stage of society development, organizational culture management problems were highlighted in the works of L. N. Aksenovskaya, according to whom, organizational culture is a complex socio-psychological order of the organizational and management interactions constituted and regulated by the interaction of participants' ethical values systems [9]. In the researches of I. V. Groshev and V. M. Yuriev the notion of "organizational" culture is applied to the local branch organization, based on codes of conduct [10]. According to I. S. Shapovalova, organizational culture is a social phenomenon of organizations, which includes the elements of organizational ideology and control subject and object characteristics which are respectively combined in personnel subsystems, ideological and management subsystems of organizational culture [11]. The various aspects of higher vocational education institutions' organizational culture formation and development are set out in the works of T. Antopolskaya [12]. From the author's viewpoint, affecting the development of each entity organizational culture creates conditions for their activity as unique "Is", united in a single space and manifested in "We" feeling, giving rise to the complicity phenomenon. The complicity manifests itself in mutual acceptance, mutual trust, mutual respect and in empathy for the success of the common cause.

The works of K. Anderson and C. Kerr considered the problem of customer-centered management as a factor of modern organizations' competitiveness improvement [13]. The economic effect of customer-centered approach, creation and implementation by companies has been studied by researchers since the 1990s [14-19]. The researchers emphasize the need to consider the features of their institutional environment for the adaptation of both theoretical and empirical tools used in practice [20-21]. The practical tools for the measurement of customer-centeredness proposed by J. S. Narver and S. F. Slater and R. Deshpande, J. Farley and F. E. Jr. Webster in the 1990s are currently used as the basis for customer-centeredness studies in Russia [22-24]. As an independent concept, customer-centeredness represents an approach according to which the customer's needs and interests are of paramount importance.

The common specific features of higher education institutions' socio-cultural component were considered based on the ideas of J. Peppers, M. Rogers, which allowed identifying the problem of modern universities' relationship with internal and external customers [25]. According to A. A. Chubatyuk, a customer-centered approach implies the active introduction of marketing philosophy, concepts and tools into an enterprise's management system [26].

The analysis of domestic and foreign literature dedicated to the research problem leads to the conclusion that, at present, the humanities have accumulated significant amount of theoretical and empirical material on the issue of organizational cultural impact on higher education institutions' specialists' training effectiveness. At the same time, it can be concluded that there is a significant deficit of researches aimed at developing technologies and mechanisms to improve modern educational institutions' organizational culture customer-centeredness.

\section{RESEARCH METHODOLOGY}

The first stage of the research was conducted in the period September to November 2016. The sample consisted of 801 respondents. The total sample included the following sociodemographic groups: on the basis of sex: men - $45.02 \%$, women $-54.98 \%$. Based on the professional orientation of the respondents' universities, the distribution was as follows: humanities $-61.86 \%$, technical studies $-38.14 \%$. In terms of the universities' status: state universities $-71.48 \%$, private universities $-28.52 \%$.

\section{INSTRUMENT}

The research used a system of key terms, concepts and indicators, based on the "objectives tree" principle. At the same time, the original concept is "customer-centered university organizational culture". The diagnostic model of customer-centered university organizational culture was developed on the basis of the generated "objectives tree". It included a set of concepts and indicators to be measured.

Simple and cross-data pooling revealing statistically significant differences between the respondents' groups selected on the basis of university affiliation, course of study, sex and other socially significant features were the main primary sociological information treatment methods. The software product "YES System" (version 5.0) (determination analysis) was used for the processing and analysis of quantitative, qualitative (non-quantitative) and mixed data. 


\section{FINDINGS AND DISCUSSION}

The main condition for university customer-centered organizational culture formation is the introduction of a customer-centeredness philosophy in all of a university's structures. Additional value creation chain - i.e. focus on customer - consumer services - permeates university customer-centered organizational culture formation and development. In this case, university customer-centeredness is considered, firstly, as the orientation of each member to the customer (each member's orientation level assessment) and secondly, the assessment of the level of the customer's satisfaction with services allows for evaluating the level of customer-centeredness as a whole, without attempting to identify the orientation of each member. Additional value creation chain generally comprises ideological, regulatory and front-office levels and cannot be formed at one level bypassing the others. Therefore, the key aspect is the collection and effective use of information about services to consumers, both real and potential ones.

The diagnostic model of university customer-centered organizational culture was developed in order to study higher education institutions' customer-centered organizational culture formation and development level. The model included the following components group:

1) university customer-centered organizational culture extent at various levels (general ideological, regulatory and front-office);

2) degree of students' needs satisfaction within the university environment;

3) degree of students' involvement in the university organizational culture and the effectiveness of university organizational cultural impact on them.

University customer-centered organizational culture parameters were developed for each of the research components.

The extent of customer-centered organizational culture at the university at a general ideological level consists of university customer-centered organizational culture development strategy elaboration and implementation, including the philosophy, mission and ideology of the university development. According to the research results, when choosing a university, the respondents were guided by the presence of the desired subjects $(64.60 \%)$, education quality provided by the university $(49.83 \%)$, and the university's prestige $(25.77 \%)$. Such factors as parents' advice $(19.24 \%)$, friends, acquaintances and relatives having studied and studying in the university $(17.18 \%)$, as well as reasonable tuition fees $(14.78 \%)$ were rather significant motivators in selecting a university. Thus, quality, prestige and acceptability are the determinants which affect the choice of an institution.

University development strategy was one of the research parameters. Almost half of the respondents (46.74\%) believe that the universities' development strategy is aimed at qualitative education, followed by the creation of favorable learning environment $(43.30 \%)$. Undoubtedly, this is a quite positive trend that characterizes not only students' understanding of higher education institution development strategy, but also the actual purpose of the university environment. This means that the universities of Belgorod region develop dynamically in the modern conditions of higher education, in compliance with federal requirements and standards, and they position themselves as customer-centered social organizations. At the same time, $39.86 \%$ of respondents stated that university development strategy is focused on attracting more students, as well as gaining the maximum profit from the services provided $(24.74 \%)$. In the authors' view, this determines the realistic positioning of the university as an institution that provides educational services under the conditions of the current commercialization of higher education.

The extent of university customer-centered organizational culture at the regulatory level consists in generated regulatory norms, values, behavior patterns, and employees' motivation. In this case, not only is employees' value orientation important, but also organization-wide commitment to creating values for the customer. The way of the process implementation in practice seems to be rather relevant and this is reflected in employees' activity.

Almost half of the respondents $(49.14 \%)$ believe that the traditions and customs, enshrined norms and codes of conduct as well as values are an integral part of university life, shared by all the participants of the educational process. However, $24.40 \%$ of respondents believe they are declared rather, than real in nature, and $20.27 \%$ agree that they exist, but are not shared by all the participants of the educational process. $5.15 \%$ of the respondents strongly believe in their absence. In the authors' view, the distribution of these answers on the one hand indicates that such university organizational culture elements as traditions, customs, enshrined norms, codes of conduct and values are typical for higher education being shared by all its participants indicates the focus of the university on its "product", but, on the other hand, they are also declarative in their nature.

The extent of university customer-centered organizational culture at the regulatory level, as well as degree of students' needs satisfaction with university environment were examined by estimating the degree of teaching staff personal and professional skills. Based on this data, a hierarchy of teaching staff personal and professional qualities can be built: professionalism, personal qualities, communication patterns and competencies, methods and techniques for reaching out to students; motivation and individual approach. Moreover, a university research revealed a relatively low level of teaching staff loyalty and involvement in the educational process due to excessive workload and fear of losing the job.

The extent of university customer-centered organizational culture at the front-office level, represented by crossfunctional interaction (communication, image and branding), was measured by means of a study of university activity management. More than half of the respondents noted the solidarity of all the structural units $(57.39 \%)$. But in this case, it is the respondents' curriculum which is the dependent variable determining their answers. Whereas $75.58 \%$ of firstyear students state there is streamlined and cohesive work of 
all structural units, only $40.59 \%$ of their senior counterparts think the same way. Also, depending on the year in which a student is, he or she determines all university structural units' degree of cohesion differently. Thus, as a student gets integrated into the students' community, gets identified with it, he or she assesses a university's activity management in terms of quality relying on his or her experience of interaction with the university structural units.

Such a parameter as focus (specialization) of a university on internal and external customers was measured by estimating university priorities. According to half of the respondents $(51.20 \%)$, the most important university unit is its administration. The student, as a key figure, comes second $(22.68 \%)$. At the same time, $13.75 \%$ of the respondents were undecided (that is 110 people in absolute terms). Of interest is the fact that only $12.37 \%$ of the respondents considered the professor as the main figure in the university while staff generally wasn't ranked at all. Moreover, the research results showed that at enrollment stage the university is focused on the entrants, while at teaching stage - on teachers and other employees of the university, and only after that comes the student as an educational process product. This university specialization approach determines the degree of its orientation at the main customers of the educational environment (entrants, students, professors and other staff of a university, parents).

Measurement of the extent of students' needs satisfaction conducted in the university environment showed that the respondents are more satisfied with the modernization of the university and its services (sports facilities, playgrounds, swimming pools (4.40), landscaping, comfort and cleanliness of classrooms (4.35), library, services provided (4.28) The following six items valued by respondents within 4 points represent values, aesthetic and general cultural norms (4.22; $4.10 ; 4.02)$, and the professionalism of the teaching staff along with the quality of educational services (4.21 and 4.03). The degree of students' needs satisfaction with the university environment was measured by examining indicators of respondents' dissatisfaction when interacting with the teaching staff of a university. The main components of students' dissatisfaction are expressed by teachers' being excessively busy $(46.05 \%)$, lack of communication between students and teachers $(25.09 \%)$, detachment of teachers from students, lack of a positive atmosphere $(23.02 \%)$, and, as a consequence, the formation of problematic vectors in the university customercentered organizational culture.

The degree of students' involvement in university organizational culture and the impact of organizational effectiveness of university culture on them were measured by such the parameter - of educational services consumers' personalization. Despite a rather positive indicator - half of the respondents pointed to educational services consumers' personalization at the stage of enrollment to a university, almost half of the total number of the respondents $(45.71 \%)$ were undecided or answered this question negatively. Also, more than half of the respondents $(56.35 \%)$ state that there is regularity in monitoring the degree of students' satisfaction with the educational process in the university. However, the rest state either the selective nature of this monitoring (namely once during the period of study in the university) $(27.84 \%)$, or they note the absence of any monitoring (15.81\%).

The majority $(59.11 \%)$ of the respondents believe that the interaction of the university administration, including professors and students, are aimed at the retention of students. Only $2.41 \%$ of the respondents considered rejection of the students as the aim of university administration interaction, including professors and students. However, $38.49 \%$ of the respondents stated a neutral attitude to the student that, in the authors' opinion, means the indifference of both the administration and teaching staff towards the student. This position demonstrates, in the authors' view, that students do not feel themselves as central figures on which are focused all the areas of work necessary for self-actualization, as well as a certain detachment from the rest of the trainees and trainers involved in the educational process.

In the framework of the research of the degree of students' involvement in the university organizational culture and its impact effectiveness, the authors measured this parameter: educational services consumers' differentiation. Half of the respondents $(50.52 \%)$ report the formation of interest groups, providing outcomes for further research activities. The rest of the respondents were either undecided $(35.74 \%)$, or stated the absence of such index (13.75\%). On the one hand, this data shows a certain degree of students' differentiation, their involvement in research activities, as well as the existence of certain selection processes. But at the same time, to a lesser extent, they characterize the involvement of students in university organizational culture and emphasize a tenuous connection and cooperation between university actors.

Willingness to give a positive recommendation for an institution $(46.71 \%)$ leads to the conclusion that the total satisfaction of the customers (i.e. students) with their university selection and, consequently, the increasing role of universities' focus on the customer (customer-centeredness) are outcomes of increased competition in the market of educational services and socio-economic development of a region.

The absence of established interactions with external customers (i.e. employers) and educational institutions was the main and pronounced problem in the research of the trajectory of university customer-centered organizational culture. This trajectory is expressed by increasing students' dissatisfaction with different university specializations, i.e. their training courses. It is the final-year students who are ready to transmit the acquired knowledge, abilities and skills to their professional tasks, that show a high level of competence, being the "product" of the university educational process. But, faced with the problems of employment, they get disappointed and, as a consequence, partially lose the knowledge acquired at the university. For this reason, a clear policy of partnership in a "university-employer" system, which provides an inextricable link between student community and alumni of the university, should be the most important field of concern of a higher education institution.

The implementation of this approach is only possible with continuous monitoring of university potential customers' loyalty and services receivers' satisfaction levels, as well as 
consumers' preferences and expectations, while assessing feedback from the market actors. Such a partnership system will provide a high level of university customer-centeredness in the regional market of educational services, as well as create a platform for effective socio-economic development of a region.

\section{CONCLUSION}

Thus, the results of the research suggest the following conclusions: the development strategy of the modern university, on the one hand, is aimed at meeting the needs of students, but on the other hand, the student is not the main motivator for the university's development; customer-centered organizational culture is instead external and demonstrative, rather than internal; and the university environment makes internal and external customers detached.

\section{Acknowledgment}

This article was prepared with the financial support of the Russian Foundation for Basic Research, Department of Humanities and Social Sciences and the Government of Belgorod region. Grant "University customer-centered organizational culture as the factor of effective social and economic development of a region" No. 16-13-31002.

\section{References}

[1] I.A. Demenenko, I.V. Shavyrina, "Genesis of the paradigm of University organizational culture," Belgorod, 2016.

[2] I.A. Gulei, O.A. Smolenskaya, I.V. Shavyrina, V.A. Shapovalova, "Conceptual bases of formation customer-oriented organizational culture of the high school," Journal of Advanced Research in Law and Economics, Iss. 6, vol.3, pp. 551-559, 2015.

[3] B. Sorensen Jesper, "Note on Organization Culture," Stanford, CA: Stanford Graduate School of Business, 2009.

[4] K.S. Cameron, R.E. Quinn, "Diagnosing and Changing Organizational Culture," Addisson-Wesley Publishing Co, 1999.

[5] P.R. Harris, R.T. Moran, "Managing cultural differences," N.Y., 1991.

[6] S.P. Robbins, "Organizational Theory: Structure, Design and Application," Englewood Cliffs, NJ, 1987.

[7] E. Schein, "Organizational Culture and Leadership," San-Francisco, 1985.

[8] G. Hofstede, "Culture's consequences", Beverly Hills, 1980.

[9] L.N. Aksenovskaya, "Order concept of organizational culture: methodological issues," Saratov, 2005.

[10] I. V. Groshev, V. M. Yuryev, "Management of organizational culture," M., 2010. (in Russian).
[11] I.S. Shapovalova, "Organizational culture modeling", Belgorod, Publishing house of BSU, 2009. (in Russian).

[12] T. Antopolskaya, "University organizational culture in the theory, social conceptions of students and learning technologies," Alma mater: high school herald, vol. 7, pp. 3-9, 2005.

[13] K.Anderson, C.Kerr, "Customer Relationship Management," McGrawHill Education, London, 2001.

[14] J.C. Narver, S. F. Slater, "The Effect of a Market Orientation on Business Profitability," Journal of Marketing, Issue 54. vol. 4, pp. 20-35, 1990.

[15] R.W. Ruekert, "Developing a Market Orientation: An Organizational Strategy Perspective," International Journal of Research in Marketing, Iss. 9, vol.3, pp. 225-245, 1992.

[16] R. Deshpande, J.U. Farley, F.E.Jr. Webster, "Corporate Culture Customer Orientation, Innovativeness in Japanese Firms: A Quadrad Analysis," Journal of marketing, Iss. 57, vol. 1, pp. 23-37, 1993.

[17] D.Vorhies, M. Harker, "The Capabilities and Performance Advantages of Market-Driven Firms: An Empirical Investigation," Australian Journal of Management, Issue 25, vol. 2, pp. 145-171, 2000.

[18] P.D. Ellis, "Market Orientation and Performance: A Meta-Analysis and Cross-National Comparisons," Journal of Management Studies, Issue 43, vol. 5, pp. 1089-1107, 2006.

[19] F.Jacob, "Preparing Industrial Suppliers for Customer Integration", Industrial Marketing Management, Issue 35, vol. 1, pp. 45-56, 2006.

[20] S.M. Burgess, J.B. Steenkamp, "Marketing Renaissance: How Research in Emerging Markets Advances Marketing Science and Practice," International Journal of Research in Marketing, Iss. 23, vol. 4, pp. 337$356,2006$.

[21] J. Sheth, "Impact of Emerging Markets on Marketing: Rethinking Existing Perspectives and Practices," Journal of Marketing, Issue 74, vol. 4, pp. 166-182, 2011.

[22] O.U. Yuldasheva, O.I. Shirshova, "Companies marketing focus: research methodology and measurement," Herald of Corporate Law, Management and Venture Investment Research Centre of Syktyvkar State University, vol. 3, pp. 96-112, 2013.

[23] A.G. Rozhkov, V.A. Rebyazina, M.M. Smirnova, "Company Customer focus: Results of an empirical test on the example of the Russian market," Russian Management Review, Iss. 12, vol. 3, pp. 33-58, 2014.

[24] O.V. Gulakova, V.A. Rebyazina, M.M. Smirnova, "Specificity of customer-companies in the Russian market: results of empirical research", Vestnik of Saint Petersburg University: Management, vol. 4, pp. 39-73, 2015.

[25] D. Peppers, M. Rogers, "Managing Customer Relationship: A strategic Framework," 2011.

[26] A.A. Chubatyuk, "Theory and methodology of customer-centered business formation," St. Petersburg, 2011. 